\title{
Reactive Arthritis: From Clinical Features to Pathogenesis
}

\author{
Ethelina Cargnelutti ${ }^{1,2}$, María Silvia Di Genaro ${ }^{1,2^{*}}$ \\ ${ }^{1}$ Division of Immunology, Faculty of Chemistry, Biochemistry and Pharmacy, National University of San Luis, San Luis, Argentina; \\ ${ }^{2}$ Laboratory of Immunopathology, Multidisciplinary Institute of Biological Investigations-San Luis (IMIBIO-SL), National Council \\ of Scientific and Technical Investigations (CONICET), San Luis, Argentina. \\ Email: *sdigena@unsl.edu.ar
}

Received October $27^{\text {th }}, 2013$; revised November $20^{\text {th }}, 2013$; accepted December $10^{\text {th }}, 2013$

Copyright (C) 2013 Ethelina Cargnelutti, María Silvia Di Genaro. This is an open access article distributed under the Creative Commons Attribution License, which permits unrestricted use, distribution, and reproduction in any medium, provided the original work is properly cited. In accordance of the Creative Commons Attribution License all Copyrights (C) 2013 are reserved for SCIRP and the owner of the intellectual property Ethelina Cargnelutti, María Silvia Di Genaro. All Copyright (C) 2013 are guarded by law and by SCIRP as a guardian.

\begin{abstract}
Reactive arthritis (ReA) is a sterile synovitis which occurs after a gastrointestinal or urogenital infection. ReA belongs to Spondyloarthritis (SpA), a group of diseases that share several clinical and radiological features including familiar clustering, absence of rheumatoid factor and association with HLA-B27. Clinically, ReA is characterized by an asymmetric arthritis predominantly affecting the lower limbs, often associated with urethritis, conjunctivitis and other extraarticular symptoms. The ReA prevalence depends on the incidence of causative pathogens. The ReA diagnosis is based on clinical features and serological tests to evidence previous infection. Different treatment including antibiotics, disease modifying antirheumatic drugs (DMARs) and biologic agents has been recommended. Even though knowing that infections trigger the joint inflammation, the ReA pathogenesis remains to be poorly understood. Several animal models and in vitro studies have been used to elucidate the mechanisms involved in ReA development. In this sense, HLA-B27 transgenic rat or mice have been used to explain the role of this molecule in SpA aetiopathogenesis. Moreover, the infectious model of Yersinia-induced ReA in rodents has shed some lights on the relationship between host genetic susceptibility to infection and abnormal immune response in ReA development. Understanding the immune mediators triggering ReA will contribute to find a specific treatment for this arthritis. In this review, we focus on clinical features, epidemiology, treatment, and the different attempts to understand the pathogenesis of ReA.
\end{abstract}

Keywords: Reactive Arthritis; HLA-B27; Spondyloarthritis; Yersinia-Induced ReA; Therapy

\section{Introduction}

Reactive arthritis (ReA) is arthritis that arises following a gastrointestinal or urogenital infection. It is a form of Spondyloarthritis (SpA), a group of diseases with common features including inflammatory arthritis (generally an asymmetrical oligoarthritis), absence of rheumatoid factor and genetic association with the human leukocyte antigen (HLA)-B27. In addition to ReA, SpA also includes ankylosing spondylitis (AS), psoriatic arthritis (PsA), arthritis related to inflammatory bowel disease (IBD-SpA) and undifferentiated SpA (U-SpA) [1]. Nevertheless, at present it exist a discussion whether this classification represent alternative presentations of one entity with heterogeneous phenotype [2]. Currently, according to the Assessment of Spondylo Arthritis International Society

${ }^{*}$ Corresponding author.
(ASAS) classification criteria (2009-2011), the SpA is classified as axial and peripheral arthritis [3].

The term "ReA" was introduced by Avohen et al. in 1969 to describe arthritis induced by Yersinia enterocolitica [4]. Moreover, the clinical features of this disease were characterized and the diagnosis of the preceding infection through serological methods was established [5]. The name ReA involves the immunological origin of this arthritis in which microorganisms do not enter in the joint cavity and antibiotic treatment has no effect on its development or outcome [6]. Even though none cultivable microorganism has been isolated from the joints of patients with ReA, bacterial antigens have been demonstrated in synovial fluid or tissue using different techniques, indicating deficient clearance of the inducer bacteria [7-10]. In addition, Chlamydia trachomatis mRNA has been detected in the joints of patients with post-ve- 
nereal ReA, raising the possibility that viable forms of this microorganism may be present $[11,12]$.

A controversy exists in relation to the clinical findings to diagnose ReA [13]. According to the 4th International Workshop on Reactive Arthritis (Berlin, 1999), the term ReA must apply to a patient with typical clinical features of this disease and in those whose preceding infection was caused by the classic microorganisms involved in their development. The minimum time interval between the gastrointestinal/genitourinary infection symptoms and arthritis should be of 1 - 7 days, maximum 4 weeks. It is advisable for the investigation of microorganisms inducers of ReA by culturing urine/feces or through serological methods [14]. The current diagnosis of ReA is performed considering clinical features, radiologic examination and laboratory tests. However, for diagnosis of ReA, there is not a single laboratory test, and the radiological images do not help much in diagnosing an acute episode. The investigations performed to ReA diagnosis, and also to make a differential diagnosis are based on hematologic, microbiologic, serologic and radiologic findings, and on synovial fluid studies (Table 1).

\section{Epidemiology}

The incidence and prevalence of ReA depends of geographic region and the prevalence of causative pathogens. The ReA incidence is estimated to be 5 - 14/100,000 patients aged 18 - 60 years $[15,16]$. Most patients are aged 20 - 40 and it is more common in Caucasians affecting equally men and women [16]. A population-based study in Oregon and Minnesota (US) reported a ReA incidence following documented enteric bacterial infections ranged from 0.6 to 3.1 cases per 100,000 , depending upon the organism [17]. Two registry-based studies from Spain reported that $1.2 \%$ to $1.4 \%$ of all patients with SpA was diagnosed with $\operatorname{ReA}$ [18]. A recent epidemiological study in Argentina informed that from 402 patients with SpA aged 38.3 - 58 years, 25 (6.2\%) had ReA [19]. In outbreaks triggered by a single source of infection, $0 \%$ $22 \%$ of infected subjects developed subsequent ReA [20].

The HLA-B27 antigen is found in 30\% - 70\% of patients with $\mathrm{ReA}$, which is a lower frequency compare to others SpA, such as AS with 90\% of patients positive for this antigen [21]. Patients with this molecule manifest a more severe arthritis with a tendency to progress to a chronic stage and also they have greater chance of developing extra-articular symptoms [22]. At present, there are descript more than 100 isoforms of the HLA-B27 molecule (http://www.ebi.ac.uk/ipd/imgt/hla) that differ in the aminoacidic sequence. Most HLA-B27 molecules seem to be associated with SpA; however, there would be a hierarchy of association between the different subtypes of these molecules. Thus, HLA-B*2704 shows higher association with SpA, followed by HLA-B*2705, HLA-B*2702 and HLA-B*2707, while HLA-B*2706 and HLA-B*2709 are less associated to these diseases [23]. Furthermore, there is a geographical distribution of these isoforms, with a prevalence of HLA-B*2704 and HLA-B*2707 for Asians, and HLA-B*2705 and HLA$B * 2702$ for Caucasians [24]. In regional studies in South America, the most frequent HLA-B27 isoforms are HLAB*2705 and HLA-B*2702 [25-27]. In Argentina, it is estimated a prevalence of $4 \%$ of HLA-B27 in the general population [28]. A study in 11 Rheumatology Centers in Argentina reported in 405 patients with SpA that 50\% of patients with ReA were positive for HLA-B27 [29].

Table 1. Methods and expected results for ReA diagnosis.

\begin{tabular}{|c|c|}
\hline \multirow[t]{6}{*}{ Hematology } & Erythrocyte sedimentation rate (ESR): usually elevated. \\
\hline & C-reactive protein level (CRP): usually elevated. \\
\hline & Complete blood cell count: in the acute phase may show leukocytosis. \\
\hline & Rheumatoid factor: negative. \\
\hline & Antinuclear antibody: negative. \\
\hline & HLA-B27 testing: not diagnosis, but has prognostic value as positive results may indicate more serious disease. \\
\hline \multirow[t]{2}{*}{ Microbiology } & Urine culture: may be positive for Chlamydia at the beginning of the infection. \\
\hline & Stool culture: positive for Salmonella, Shigella or Yersinia whether obtained early. \\
\hline \multirow[t]{3}{*}{ Synovial fluid studies } & Cell count: at early time of ReA is high and dominated by polymorphonuclears. \\
\hline & Microscopy under polarized light: negative for urate crystals. \\
\hline & Synovial fluid culture: negative. \\
\hline Serology & $\begin{array}{l}\text { Antibodies against Yersinia, Salmonella, Campylobacter, Chlamydia, Neisseria gonorrhoeae, Borrelia burgdorferi, and also } \\
\text { against } \beta \text {-hemolytic streptococci should be determined and followed: positive for Salmonella, Shigella, Yersinia or Chalmydia. }\end{array}$ \\
\hline \multirow[t]{2}{*}{ Radiological images } & $\begin{array}{l}\text { Early disease: soft tissue swelling around affected joints that can represent large effusions; tendon swelling as in the calcaneal } \\
\text { region. }\end{array}$ \\
\hline & $\begin{array}{l}\text { Chronic disease: bone and cartilage erosions with adjacent bone proliferation specially in the lower extremities; paravertebral } \\
\text { ossification. }\end{array}$ \\
\hline
\end{tabular}




\section{Clinical Features}

The classic clinical characteristics of ReA involve an axial joint arthritis, enthesitis and peripheral oligoarthritis (less than 5 joint affected) usually asymmetrically accompanied by extra-articular symptoms [30]. The musculoskeletal symptoms are commonly acute and at beginning associated with systemic features such as malaise, fever, fatigue and weight loss [31].

Urogenital infection precedes 1 - 6 weeks the musculoskeletal symptoms. Their presentation varies from mild to severe with prostatitis or cervicitis. However, it can be asymptomatic in both sex. It is often accompanied by other signs such as penis discharge in males, pain with urination, or hematuria [32]. On the other hand, acute diarrhea appears approximately one month before articular manifestations in post-dysenteric ReA. Gastrointestinal symptoms are absent or mild in ReA triggered by Yersinia, unlike in patients with Salmonella and Campylobacter infections where symptoms are more severe and of longer duration [33].

Joint inflammation could be axial, involving the lumbar spine or sacroiliac joints, alternatively it is peripheral, commonly affecting the large joints of lower extremities, being knees, foot joints and ankles the most frequently involved. However, affectation of upper extremities (elbow, shoulder) and polyarticular forms have been reported in which the subtalar, metatarsophalangeal and toe interphalangeal joints tend to be affected $[34,35]$. Some patients suffer from dactylitis which is a diffuse swelling of entire finger or toe, sometimes referred as "sauce digit". This feature is common in ReA, but also in PsA and it is used to make a diagnosis of axial SpA using the ASAS criteria [36] or PsA using the ClASsification criteria for Psoriatic ARthritis (CASPAR) [37].

Enthesitis is an inflammation of the transitional zone where tendons and ligaments insert into the bone and sometimes it is the unique manifestation of this arthritis. Achilles tendonitis and plantar fasciitis are the most common types of enthesitis in ReA, but another enthesis can be involved [38].

Extra-articular symptoms are frequently observed in ReA and include mucocutaneous, ocular and occasionally cardiac manifestations. Mucocutaneous lesions are very specific of ReA and more frequent in HLA-B27 positive patients. Circinate balanitis is the most common skin manifestation of this arthritis following by keratoderma blennorrhagicum, occurring in almost $50 \%$ and $10 \%$ of the patients, respectively [39]. A well recognized complication of Yersinia-infection is erythema nodosum which is a painful rash predominantly on the extensor surfaces of the arms and legs [40]. Nails changes (nail dystrophy, subungual debris, and periungual pustules), hyperkeratosis and oral lesions also may occur [38].

One-third of patients with ReA suffer of conjunctivitis once it is established, being more common after a genitourinary infection or enteric infection by Shigella, Salmonella and Campylobacter. The conjunctivitis is unilateral or bilateral with a mucopurulent discharge and its course is often mild and transient [41]. Acute anterior uveitis (AAU) may be observed in about a 5\% patients with acute ReA and more than 50\% patients with AAU are HLA-B27 positive. This manifestation is very painful and is characterized by sudden-onset, mostly unilateral [42-44]. Others less frequent ocular symptoms are keratitis [45], corneal ulceration, retrobulbar neutritis, scleritis and hypema which appear in persistent or chronic ReA [28]. The persistence of ocular inflammation may result in complications such as posterior synechiae, glaucoma, cystoids macular edema and cataract formation [46].

Cardiovascular manifestations in ReA and in other members of the SpA family have long been recognized and related to HLA-B27 positivity. Disturbances of the cardiac conduction system are found early $[47,48]$ and cases with severe aortic insufficiency are found in late disease [49].

\section{Triggering Microbes}

Different bacteria species are associated with ReA development [15]. The classical enteric pathogens capable of triggering this arthritis belong to the genders Salmonella, Yersinia, Shigella and Campylobacter. On the other hand, $C$. trachomatis is the most common urogenital pathogen related to ReA [11,12]. Salmonella, Yersinia, Shigella and Campylobacter are Gram-negative bacteria with lipopolysaccharide (LPS) in their outer membrane. Furthermore, they are facultative or obligate intracellular, aerobic or microaerophilic bacteria. These characteristics probably account for their relation with ReA [31]. Epidemiological studies support the high association between infection with these bacteria and ReA development. Thus, in a study performed in different Rheumatology clinics in Berlin, Germany, from 52 patients with ReA a causative pathogen was identified in 29/52 (56\%) [50]. In 17 (52\%) of the patients with enteric ReA one of the enteric bacteria was identified: Salmonella in 11/33 (33\%) and Yersinia in 6/33 (18\%). C. trachomatis was the causative pathogen in 12/19 (63\%) of the patients with urogenic ReA [50]. In 74 patients with the clinical picture of U-SpA, a specific triggering bacterium was also identified in 35/74 (47\%) patients: Yersinia in 14/74 (19\%), Salmonella in 9/74 (12\%), and C. trachomatis in 12/74 (16\%) [50]. Moreover, a 2-year epidemiological study on ReA and possible ReA in Oslo (Norway) reported an annual minimum incidence of Chlamydia-induced ReA $(n=25)$ of $4.6 / 100,000$, and of enteric ReA $(n=27)$ of 5/100,000 individuals between 18 and 60 years [16]. In addition, a population-based cohort study $(n=71)$ in Southern Sweden showed in patients with a 
new-onset arthritis that $45 \%$ had had a prior infection, 27 (38\%) had ReA and Campylobacter-induced ReA dominated the ReA group [51]. In addition, in a study performed in our laboratory in patients with musculoskeletal symptoms, we found immunoglobulin (Ig) A to Yersinia LPS in 13/124 (6\%) sera and in 3/47 synovial fluids (6\%). By Western blot, IgA to Yersinia outer proteins (Yops) was found in 14/124 sera (11\%) and 2/47 synovial fluids (4\%) [52].

Among the less common triggering microorganisms Clostridium difficile and pathogens strains of Escherichia coli have been described cause ReA [17,53,54]. Other microorganisms have been implicated as potential causes of ReA, these include Chlamydia pneumoniae [55,56], Ureaplasma urealyticum [57], Helicobacter pylori [58] and multiple intestinal parasites [59-61]. Nevertheless, most descriptions involving these microorganisms are isolated cases and even in discussion [38].

\section{Pathogenesis}

Despite knowing the initial event (gastrointestinal or urogenital infection), the pathogenesis of ReA is not completely understood. Environmental and genetic factors are involved and different aspects should be considered in the development of ReA including impaired elimination of causative microbes, persistence of their antigens in the joints, host immune response and genetics factors like the presence of the molecule HLA-B27 (Figure 1).

The classical bacteria triggering this arthritis are invasive and cause primary infection in the gastrointestinal (enteric pathogens) or genitourinary mucosa (C. thrachomatis), from there they disseminate to other organs such as lymphoid tissue, spleen and liver [28]. As mentioned above, mRNA of $C$. thrachomatis and DNA from other enteric pathogens or their products have been de-

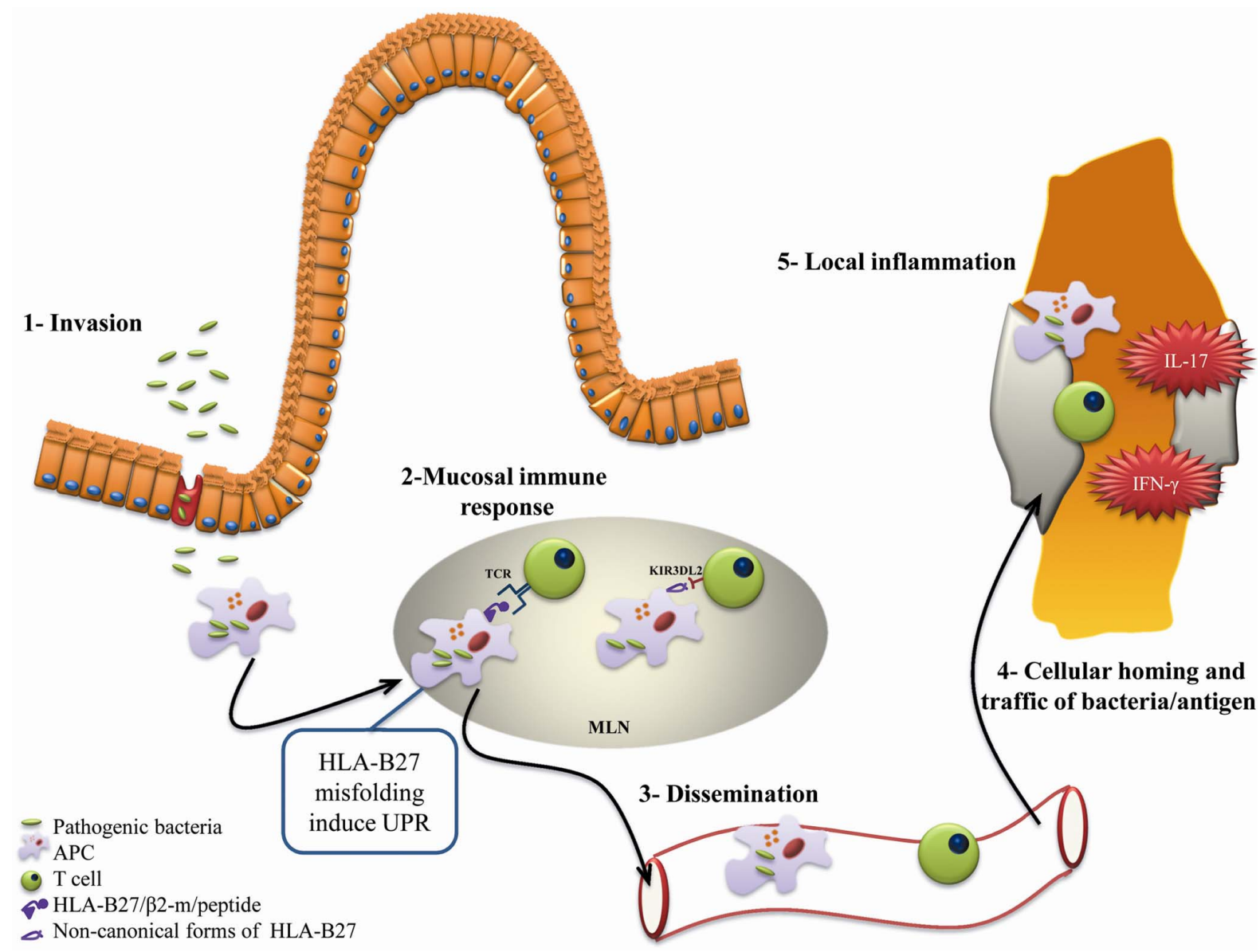

Figure 1. Model of ReA pathogenesis. (1) Pathogenic bacteria attach and invade the intestinal epithelium. HLA-B27 in antigen presenting cell (APC) such as macrophages may be responsible for bacterial persistence; (2) In mesenteric lymph node (MLN), APC could present arthritogenic peptides through HLA-B27 to CD8 ${ }^{+} \mathrm{T}$ cells, or HLA-B27 itself could be recognized through killer immunoglobulin receptor (KIR)3DL2 on $\mathrm{CD}^{+} \mathrm{T}$ cells. Moreover, HLA-B27 misfolding induces an unfolded protein response (UPR); (3-4) APC with non-active bacteria or with bacterial antigens, and T cells disseminate within peripheral blood and eventually reach the joint; (5) In the target joint, gut derived APC and T cells induce immune response with IFN- $\gamma$ and IL-17 production, recruitment of other cells and induction of mesenchymal cells activation, which enhance and sustain inflammation. 
tected in the synovial fluid or tissue of patients with ReA. These facts demonstrate that the entire bacteria or their products traffic from the initial site of infection to the joint. On the other hand, persistence of $Y$. enterocolitica has been informed in peripheral blood up to 4 year after initial infection in patients with ReA [62], as well in different organs in ReA rat models [63]. Furthermore, persistence of Salmonella enteritidis has been demonstrated in human epithelial cells after 14 days of in vitro infection [64]. The impaired elimination of causative microbes plus the traffic of their antigens to the joint could be responsible of pathological immune response in the joint [28]. However, the detailed mechanisms by which those antigens reach the joint and induce inflammation remain to be fully elucidated.

An imbalance in the cytokine levels may be responsible for persistence of causative microbes and also reflect the pathological immune response in the joint. In this way, diminished levels of TNF produced by peripheral blood mononuclear cells (PBMC) of patients with ReA [65] and elevated amounts of IL-10 have been demonstrated at the beginning of the disease [66]. However, in patients at chronic stage of arthritis, elevated amounts of TNF produced by PBMC and $\mathrm{CD}^{+} \mathrm{IFN}^{-} \gamma^{+}$cells from blood and synovial fluid have been reported [66]. Another authors observed in patients with ReA enriched amounts of $\mathrm{CD} 4^{+} \mathrm{IL}-17^{+}$cells within synovial fluid supporting the hypothesis that IL-17 could contribute to pathogenesis of $\operatorname{ReA}$ [67]. In line with these results, we detected higher IL-17 and IFN- $\gamma$ levels in regional lymph nodes of $T N F R p 55^{-/}$mice with $Y$. enterocolitica-induced ReA and significantly increased number of CD4 ${ }^{+} \mathrm{IL}-$ $17^{+}$cells in these mice compared to their counterpart wild-type [68]. In addition, in this animal model we observed decreased amounts of IL-10 and Treg cells at arthritis onset (day 14 after infection) in contrast with chronic stage of arthritis [69]. These works and others advocate the idea that in $\operatorname{ReA}$, a specific cellular immune response take place in the joint and chronic stimuli allows to the cells maintain the inflammatory process for long periods [70].

The first genetic factor described to be related to ReA and SpA in general, is the molecule HLA-B27. The role of HLA-B27 in SpA is not completely known and several hypotheses try to explain it. Since HLA-B27 is a class I histocompatibility molecule, it has been postulated that it presents arthritogenic bacterial peptides to $\mathrm{CD}^{+} \mathrm{T}$ cells, thus stimulating an autoimmune response (molecular mimicry) [71-73]. However, in HLA-B27/human $\beta 2-$ microglobulin (h $\beta 2-\mathrm{m})$ transgenic rats, two different approaches demonstrated that $\mathrm{CD}^{+} \mathrm{T}$ cells are not necessary for development of SpA-like phenotype. Furthermore, the depletion of $\mathrm{CD}^{+} \mathrm{T}$ cells through antibodies [74] or the elimination of $\operatorname{CD} 8 \alpha$ protein expression by chemical mutation of $C D 8 \alpha$ gene [75] does not prevent disease in this SpA rodent model.

It was found that heavy chains of HLA-B27 have a tendency to misfold forming homodimers and heterodimers due to aberrant disulfide bound formation by unpaired Cys residues at position 67 [76]. HLA-B27 misfolding causes a stress response in the endoplasmic reticulum and the cell activates multiple signaling pathways that orchestrate what is known as the unfolded protein response (UPR). One consequence of UPR activation is the polarization of cell to responding to patter recognition receptors (PRR) agonists (TLR 4, 2 and 3) toward the production of greater amount of IL-23 over IL-12, which in turns provide a stimulus for Th17 survival and activation in individual with permissive IL-23R polymorphism [77]. Additionally, the non-canonical forms of HLA-B27 antigen expressed on cell surface are plausible to be recognized by killer immunoglobulin receptors (KIR) such as KIR3DL2 on $\mathrm{CD}^{+} \mathrm{T}$ cells, and then, trigger inflammation $[1,21,78]$.

Other genetic factors (e.g. $I L-23 R, I L-1 R 2, T N F R S 1$, $T R A D D$, etc.) has been associated with AS, PsA and IBD-SpA [79]; therefore, it is possible that these factors may also have significance in ReA since even individuals negative for HLA-B27 also develop ReA following mucosal infection.

\section{Treatment}

Since infections trigger ReA, the use of antibiotic therapy in this arthropathy has been proposed and it is possible when the trigger bacterium has been isolated. However, the use of antibiotics is controversial probably because several studies have been conducted enrolling patients with ReA caused by heterogeneous pathogens. Moreover, other studies have often employed antibiotic monotherapy that may be not effective in the aberrant forms of bacteria causing ReA. In contrast, a clinical trial in 2010 enrolled only patients with blood or synovial tissue positive for Chlamydia detected by PCR [80]. In this study, the patients were randomized to receive doxycycline + rifampin, azithromycin + rifampin or placebo. After six months, $63 \%$ of the patients with combination antibiotic therapy versus $20 \%$ of placebo group had clinical improvement as measured by swollen joint count [80]. Therefore, this was the first trial that provide evidence supporting antibiotic therapy efficacy in Chlamydia-induced ReA.

The current treatment of ReA is based on rest, nonsteroidal anti-inflammatory drugs (NSAIDs) [81]. In case of NSAID-resistance or active disease for more than 4 weeks, intra-articular injection of corticosteroids is recommended in patients with mono or oligoarthritis [82,83]. Topical corticosteroids are useful for ReA extra-articular symptoms such as uveitis, circinate balanitis and kerato- 
derma blennorrhagicum [84].

In chronic and severe ReA, disease-modifying antirheumatic drugs (DMARDs) are recommended and the most used is sulfasalazine (SSZ) [81] which shows limited effectiveness in patients with ReA acute episodes [85]. Another DMARD is methotrexate, which may be used as an alternative to SSZ in patients who are allergic or intolerant to SSZ or who do not respond to this drug [84]. The DMARDs treatment is an alternative to antiTNF therapy and may delay the switch to biologic agents.

The TNF antagonists such as infliximab, etanercept and adalimumab showed impressive short-term improvements in AS [86], however, data on the use of this antiTNF therapy in ReA are limited [87-92]. A largest recent experience with TNF antagonists in ReA supported the safety and efficacy of these agents in refractory ReA [89]. In this study, 10 patients with ReA previously refractory to NSAIDs and DMARDs received anti-TNF therapy within a median of 6 months (range 2 - 12 months) between the onset of ReA and the initiation of the treatment. After a follow-up of 20.6 months, no severe adverse events, including severe infection, were observed. AntiTNF therapy was rapidly effective in 9 patients (90\%), as shown by the rapid effect on a visual analog scale pain score, tender joint count, swollen joint count, and extra-articular manifestations. Only mild infections were documented, none of which were associated with the triggering infection [89].

Our findings in Yersinia-induced ReA in TNFRp55 $5^{--}$ mice demonstrated that, in the absence of TNF signaling, redundant pathways, particularly Th17 and Th1 effector cells, may act in concert to sustain inflammation in bacterial induced ReA [68]. Recently, we reported that TNFRp55 modulates macrophage functions in response to Yersinia LPS stimulation suggesting an essential regulatory role of TNF via TNFRp55 signaling [93]. Furthermore, we have reported that this pathway controlled the induction and function of Treg cells through differential regulation of cytokine production [69]. Our data support the concept that TNFRp55 signaling may participate in the modulation of immune response in ReA, suggesting caution in the use of TNF blockers in cases of chronic ReA.

Treatment switch to a second anti-TNF agent can be an effective strategy in AS. There is a need for more long-term studies to examine the longitudinal efficacy in SpA of the newer biological therapies such as golimumab, a fully human antibody anti-TNF, and rituximab, an antibody that induces B cell depletion [86]. Ustekinumab, an anti-p40 antibody blocking both IL-23 and IL-12 has demonstrated clinical efficacy in PsA [94]. Secukinumab, an anti-IL-17A antibody, has been used in a randomized controlled trial with short duration of follow-up for AS treatment showing good efficacy [86]. A trend towards improvement was also demonstrated for secukinumab in PsA [95]. Until now, these newer biological agents have not been used in patients with ReA.

\section{ReA Prognosis}

ReA usually has a self-limiting course since the most patients recover fully in 2 to 6 months. However, 15\% $30 \%$ of patients may develop chronic disease ( $>6$ months with clinical symptoms) [15]. The prognosis of enteric ReA is best known being frequent recurrent acute attacks in patients with ReA triggered by Salmonella, Shigella and Yersinia [1,15]. In a Finnish study at mean of 11 years after Salmonella-induced ReA, 8/50 (16\%) developed chronic SpA and 5 (12\%) of these patients fulfilled the criteria of AS [96]. In a similar study in 85 patients with acute Yersinia-induced ReA, half to the patients showed peripheral joint symptoms and one-third of them had radiologic evidence of sacroiliitis [97]. A 20-year follow up study found that 32/100 of patients with Shigella-induced ReA had AS [98]. Only HLA-B27 positive patients ReA developed recurrent or chronic symptoms [96]. Therefore, the prognosis is less favorable in patients who are HLA-B27 positive [28].

\section{Conclusion}

A gastrointestinal or urogenital infection may trigger ReA and genetic factors such as HLA-B27 which are associated with chronic and more severe arthritis. However, the pathogenesis of this arthropathy is not completely known. Therefore, there are no specific treatment for this disease. Anti-TNF therapy in ReA has been recommended for refractory ReA suggesting an association with cytokine response and ReA development. Our experimental evidence indicates caution in the use of TNF blockers in bacterial-triggered chronic arthritis. We believe that further investigation in animal models should delineate the immunopathogenic mechanisms involved in ReA and contribute to more specific therapeutic intervention.

\section{Sources of Funding}

This work was supported by grants from Agencia Nacional de Promoción Científica y Tecnológica (PICT 2008-763; PICT 2011-0732), Universidad Nacional de San Luis (Project 0401), M.S.D.G. is member of the Scientific Career of National Council of Scientific and Technical Investigations; E. C. is National Council of Scientific and Technical Investigations fellow.

\section{REFERENCES}

[1] M. Dougados and D. Baeten, "Spondyloarthritis,” Lancet, Vol. 377, No. 9783, 2011, pp. 2127-2137. 
http://dx.doi.org/10.1016/S0140-6736(11)60071-8

[2] D. Baeten, M. Breban, R. Lories, G. Schett and J. Sieper, "Are Spondylarthritides Related but Distinct Conditions or a Single Disease with a Heterogeneous Phenotype?” Arthritis \& Rheumatism, Vol. 65, No. 1, 2013, pp. 12-20. http://dx.doi.org/10.1002/art.37829

[3] A. Van Tubergen and U. Weber, "Diagnosis and Classification in Spondyloarthritis: Identifying a Chameleon," Nature Reviews Rheumatology, Vol. 8, No. 5, 2012, pp. 253-261. http://dx.doi.org/10.1038/nrrheum.2012.33

[4] P. Ahvonen, K. Sievers and K. Aho, "Arthritis Associated with Yersinia enterocolitica Infection,” Acta Rheumatologica Scandinavica, Vol. 15, No. 3, 1969, pp. 232-253.

[5] O. Laitenen, J. Tuuhea and P. Ahvonen, "Polyarthritis Associated with Yersinia enterocolitica Infection. Clinical Features and Laboratory Findings in Nine Cases with Severe Joint Symptoms," Annals of the Rheumatic Diseases, Vol. 31, No. 1, 1972, pp. 34-39. http://dx.doi.org/10.1136/ard.31.1.34

[6] K. Aho, P. Ahvonen, T. Juvakoski, M. Kousa, M. Leirisalo and O. Laitinen, "Immune Responses in YersiniaAssociated Reactive Arthritis," Annals of the Rheumatic Diseases, Vol. 38, Suppl. 1, 1979, pp. 123-126.

[7] C. J. Cox, K. E. Kempsell and J. S. Gaston, "Investigation of Infectious Agents Associated with Arthritis by Reverse Transcription PCR of Bacterial rRNA," Arthritis Research \& Therapy, Vol. 5, No. 1, 2003, pp. R1-R8. http://dx.doi.org/10.1186/ar602

[8] K. Granfors, S. Jalkanen, A. A. Lindberg, O. Maki-Ikola, R. Von Essen, R. Lahesmaa-Rantala, H. Isomaki, R. Saario, W. J. Arnold and A. Toivanen, “Salmonella Lipopolysaccharide in Synovial Cells from Patients with Reactive Arthritis," Lancet, Vol. 335, No. 8691, 1990, pp. 685-688. http://dx.doi.org/10.1016/0140-6736(90)90804-E

[9] J. S. Hill Gaston, C. Cox and K. Granfors, "Clinical and Experimental Evidence for Persistent Yersinia Infection in Reactive Arthritis," Arthritis \& Rheumatism, Vol. 42, No. 10, 1999, pp. 2239-2242.

http://dx.doi.org/10.1002/1529-0131(199910)42:10<2239 $\because$ AID-ANR29>3.0.CO;2-L

[10] R. Merilahti-Palo, K. O. Soderstrom, R. Lahesmaa-Rantala, K. Granfors and A. Toivanen, "Bacterial Antigens in Synovial Biopsy Specimens in Yersinia Triggered Reactive Arthritis," Annals of the Rheumatic Diseases, Vol. 50, No. 2, 1991, pp. 87-90.

http://dx.doi.org/10.1136/ard.50.2.87

[11] A. M. Beutler, J. A. Whittum-Hudson, R. Nanagara, H. R. Schumacher and A. P. Hudson, "Intracellular Location of Inapparently Infecting Chlamydia in Synovial Tissue from Patients with Reiter's Syndrome,” Immunologic Research, Vol. 13, No. 2-3, 1994, pp. 163-171. http://dx.doi.org/10.1007/BF02918277

[12] H. C. Gerard, P. J. Branigan, H. R. Schumacher Jr. and A. P. Hudson, "Synovial Chlamydia trachomatis in Patients with Reactive Arthritis/Reiter's Syndrome Are Viable but Show Aberrant Gene Expression," The Journal of Rheumatology, Vol. 25, No. 4, 1998, pp. 734-742.

[13] J. M. Townes, "Reactive Arthritis after Enteric Infections in the United States: The Problem of Definition," Clinical Infectious Diseases, Vol. 50, No. 2, 2010, pp. 247-254. http://dx.doi.org/10.1086/649540

[14] J. Braun, G. Kingsley, D. Van Der Heijde and J. Sieper, "On the Difficulties of Establishing a Consensus on the Definition of and Diagnostic Investigations for Reactive Arthritis. Results and Discussion of a Questionnaire Prepared for the 4th International Workshop on Reactive Arthritis, Berlin, Germany, July 3-6, 1999,” The Journal of Rheumatology, Vol. 27, No. 9, 2000, pp. 2185-2192.

[15] T. Hannu, "Reactive Arthritis," Best Practice \& Research Clinical Rheumatology, Vol. 25, No. 3, 2011, pp. 347357. http://dx.doi.org/10.1016/j.berh.2011.01.018

[16] T. K. Kvien, A. Glennas, K. Melby, K. Granfors, O. Andrup, B. Karstensen and J. E. Thoen, "Reactive Arthritis: Incidence, Triggering Agents and Clinical Presentation,” The Journal of Rheumatology, Vol. 21, No. 1, 1994, pp. 115-122.

[17] J. M. Townes, A. A. Deodhar, E. S. Laine, K. Smith, H. E. Krug, A. Barkhuizen, M. E. Thompson, P. R. Cieslak and J. Sobel, "Reactive Arthritis Following Culture-Confirmed Infections with Bacterial Enteric Pathogens in Minnesota and Oregon: A Population-Based Study," Annals of the Rheumatic Diseases, Vol. 67, No. 12, 2008, pp. 1689-1696. http://dx.doi.org/10.1136/ard.2007.083451

[18] E. Collantes, P. Zarco, E. Munoz, X. Juanola, J. Mulero, J. L. Fernandez-Sueiro, J. C. Torre-Alonso, J. Gratacos, C. Gonzalez, E. Batlle, P. Fernandez, L. F. Linares, E. Brito and L. Carmona, "Disease Pattern of Spondyloarthropathies in Spain: Description of the First National Registry (REGISPONSER) Extended Report,” Rheumatology (Oxford), Vol. 46, No. 8, 2007, pp. 1309-1315. http://dx.doi.org/10.1093/rheumatology/kem084

[19] E. Buschiazzo, J. A. Maldonado-Cocco, P. Arturi, G. Citera, A. Berman, A. Nitsche and O. L. Rillo, "Epidemiology of Spondyloarthritis in Argentina," The American Journal of the Medical Sciences, Vol. 341, No. 4, 2011, pp. 289-292. http://dx.doi.org/10.1097/MAJ.0b013e31820f8cc3

[20] M. Vasala, S. Hallanvuo, P. Ruuska, R. Suokas, A. Siitonen and M. Hakala, "High Frequency of Reactive Arthritis in Adults after Yersinia pseudotuberculosis O:1 Outbreak Caused by Contaminated Grated Carrots," Annals of the Rheumatic Diseases, 2013. http://dx.doi.org/10.1136/annrheumdis-2013-203431

[21] A. Mcmichael and P. Bowness, "HLA-B27: Natural Function and Pathogenic Role in Spondyloarthritis," Arthritis Research, Vol. 4, Suppl. 3, 2002, pp. S153-158.

[22] A. Toivanen and P. Toivanen, "Reactive Arthritis," Best Practice \& Research Clinical Rheumatology, Vol. 18, No. 5, 2004, pp. 689-703. http://dx.doi.org/10.1016/j.berh.2004.05.008

[23] A. Chatzikyriakidou, P. V. Voulgari and A. A. Drosos, "What Is the Role of HLA-B27 in Spondyloarthropathies?” Autoimmunity Reviews, Vol. 10, No. 8, 2011, pp. 464-468. http://dx.doi.org/10.1016/j.autrev.2011.01.011

[24] G. P. Thomas and M. A. Brown, "Genetics and Genomics of Ankylosing Spondylitis,” Immunological Reviews, Vol. 233, No. 1, 2010, pp. 162-180. 
http://dx.doi.org/10.1111/j.0105-2896.2009.00852.x

[25] R. Bonfiglioli, R. A. Conde, P. D. Sampaio-Barros, P. Louzada-Junior, E. A. Donadi and M. B. Bertolo, "Frequency of HLA-B27 Alleles in Brazilian Patients with Psoriatic Arthritis," Clinical Rheumatology, Vol. 27, No. 6, 2008, pp. 709-712. http://dx.doi.org/10.1007/s10067-007-0770-3

[26] A. Cipriani, S. Rivera, M. Hassanhi, G. Marquez, R. Hernandez, C. Villalobos and M. Montiel, "HLA-B27 Subtypes Determination in Patients with Ankylosing Spondylitis from Zulia, Venezuela," Human Immunology, Vol. 64, No. 7, 2003, pp. 745-749. http://dx.doi.org/10.1016/S0198-8859(03)00085-5

[27] B. Martinez, L. Caraballo, M. Hernandez, R. Valle, M. Avila and A. Iglesias Gamarra, "HLA-B27 Subtypes in Patients with Ankylosing Spondylitis (as) in Colombia,” Revista de Investigación Clínica, Vol. 51, No. 4, 1999, pp. 221-226.

[28] J. S. Hill Gaston and M. S. Lillicrap, "Arthritis Associated with Enteric Infection," Best Practice \& Research Clinical Rheumatology, Vol. 17, No. 2, 2003, pp. 219239. http://dx.doi.org/10.1016/S1521-6942(02)00104-3

[29] V. Bellomio, A. Berman, R. Sueldo, M. J. Molina, A. Spindler, E. Lucero, H. Berman, A. Nitsche, C. Asnal, J. A. Maldonado Cocco, G. Citera, S. Paira, C. Sandoval, R. Wong, R. Gallo, O. Rillo, R. Chaparro, A. Alvarellos, J. A. Albiero, C. Graf, A. Zunino, C. G. Casado, C. B. Romeo, J. C. Barreira and E. Aroca Briones, "Respondia. Iberoamerican Spondyloarthritis Registry: Argentina," Reumatología Clínica, Vol. 4, Suppl. 4, 2008, pp. S23-29.

[30] S. Kobayashi and I. Kida, "Reactive Arthritis: Recent Advances and Clinical Manifestations," Annals of Internal Medicine, Vol. 44, No. 5, 2005, pp. 408-12. http://dx.doi.org/10.2169/internalmedicine.44.408

[31] M. Leirisalo-Repo, "Reactive Arthritis," Scandinavian Journal of Rheumatology, Vol. 34, No. 4, 2005, pp. 251259. http://dx.doi.org/10.1080/03009740500202540

[32] W. F. Barth and K. Segal, "Reactive Arthritis (Reiter's Syndrome),” American Family Physician, Vol. 60, No. 2, 1999, pp. 499-503, 507.

[33] B. Kwiatkowska and A. Filipowicz-Sosnowska, "Reactive Arthritis,” Polskie Archiwum Medycyny Wewnętrznej, Vol. 119, No. 1-2, 2009, pp. 60-65.

[34] T. Hannu, L. Mattila, H. Rautelin, P. Pelkonen, P. Lahdenne, A. Siitonen and M. Leirisalo-Repo, "Campylobacter-Triggered Reactive Arthritis: A Population-Based Study," Rheumatology (Oxford), Vol. 41, No. 3, 2002, pp. 312-318. http://dx.doi.org/10.1093/rheumatology/41.3.312

[35] T. Rathod, A. Chandanwale, S. Chavan and M. Shah, "Polyarthritic, Symmetric Arthropathy in Reactive Arthritis," Journal of Natural Science, Biology and Medicine, Vol. 2, No. 2, 2011, pp. 216-218. http://dx.doi.org/10.4103/0976-9668.92312

[36] M. Rudwaleit, D. Van Der Heijde, R. Landewe, J. Listing, N. Akkoc, J. Brandt, J. Braun, C. T. Chou, E. CollantesEstevez, M. Dougados, F. Huang, J. Gu, M. A. Khan, Y. Kirazli, W. P. Maksymowych, H. Mielants, I. J. Sorensen, S. Ozgocmen, E. Roussou, R. Valle-Onate, U. Weber, J.
Wei and J. Sieper, "The Development of Assessment of Spondyloarthritis International Society Classification Criteria for Axial Spondyloarthritis (Part II): Validation and Final Selection," Annals of the Rheumatic Diseases, Vol. 68, No. 6, 2009, pp. 777-783.

http://dx.doi.org/10.1136/ard.2009.108233

[37] W. Taylor, D. Gladman, P. Helliwell, A. Marchesoni, P. Mease and H. Mielants, "Classification Criteria for Psoriatic Arthritis: Development of New Criteria from a Large International Study," Arthritis \& Rheumatism, Vol. 54, No. 8, 2006, pp. 2665-2673. http://dx.doi.org/10.1002/art.21972

[38] J. D. Carter and A. P. Hudson, "Reactive Arthritis: Clinical Aspects and Medical Management," Rheumatic Disease Clinics of North America, Vol. 35, No. 1, 2009, pp. 21-44.

http://dx.doi.org/10.1016/j.rdc.2009.03.010

[39] I. B. Wu and R. A. Schwartz, "Reiter's Syndrome: The Classic Triad and More," Journal of the American Academy of Dermatology, Vol. 59, No. 1, 2008, pp. 113-121. http://dx.doi.org/10.1016/j.jaad.2008.02.047

[40] B. M. Rosner, D. Werber, M. Hohle and K. Stark, “Clinical Aspects and Self-Reported Symptoms of Sequelae of Yersinia enterocolitica Infections in a PopulationBased Study, Germany 2009-2010," BMC Infectious Diseases, Vol. 13, 2013, p. 236.

[41] I. Colmegna, R. Cuchacovich and L. R. Espinoza, "HLAB27-Associated Reactive Arthritis: Pathogenetic and Clinical Considerations," Clinical Microbiology Reviews, Vol. 17, No. 2, 2004, pp. 348-369. http://dx.doi.org/10.1128/CMR.17.2.348-369.2004

[42] T. E. Feltkamp and J. H. Ringrose, “Acute Anterior Uveitis and Spondyloarthropathies," Current Opinion in Rheumatology, Vol. 10, No. 4, 1998, pp. 314-318. http://dx.doi.org/10.1097/00002281-199807000-00006

[43] M. Huhtinen, K. Laasila, K. Granfors, M. Puolakkainen, I. Seppala, L. Laasonen, H. Repo, A. Karma and M. LeirisaloRepo, "Infectious Background of Patients with a History of Acute Anterior Uveitis," Annals of the Rheumatic Diseases, Vol. 61, No. 11, 2002, pp. 1012-1016. http://dx.doi.org/10.1136/ard.61.11.1012

[44] D. Monnet, M. Breban, C. Hudry, M. Dougados and A. P. Brezin, "Ophthalmic Findings and Frequency of Extraocular Manifestations in Patients with HLA-B27 Uveitis: A Study of 175 Cases,” Ophthalmology, Vol. 111, No. 4, 2004, pp. 802-809. http://dx.doi.org/10.1016/j.ophtha.2003.07.011

[45] N. Kozeis, M. Trachana and S. Tyradellis, "Keratitis in Reactive Arthritis (Reiter Syndrome) in Childhood," Cornea, Vol. 30, No. 8, 2011, pp. 924-925. http://dx.doi.org/10.1097/ICO.0b013e3182000916

[46] S. Kiss, E. Letko, S. Qamruddin, S. Baltatzis and C. S. Foster, "Long-Term Progression, Prognosis, and Treatment of Patients with Recurrent Ocular Manifestations of Reiter's Syndrome,” Ophthalmology, Vol. 110, No. 9, 2003, pp. 1764-1769.

[47] L. Bergfeldt, "HLA B27-Associated Rheumatic Diseases with Severe Cardiac Bradyarrhythmias. Clinical Features and Prevalence in 223 Men with Permanent Pacemakers,” 
American Journal of Medicine, Vol. 75, No. 2, 1983, pp. 210-215. http://dx.doi.org/10.1016/0002-9343(83)91193-2

[48] H. Nielsen, “Complete Heart Block in Reiter's Syndrome,” Acta Cardiologica, Vol. 41, No. 6, 1986, pp. 451-455.

[49] L. E. Brown, P. Forfia and J. A. Flynn, “Aortic Insufficiency in a Patient with Reactive Arthritis: Case Report and Review of the Literature,” HSS Journal, Vol. 7, No. 2, 2011, pp. 187-189. http://dx.doi.org/10.1007/s11420-010-9184-x

[50] C. Fendler, S. Laitko, H. Sorensen, C. Gripenberg-Lerche, A. Groh, J. Uksila, K. Granfors, J. Braun and J. Sieper, "Frequency of Triggering Bacteria in Patients with Reactive Arthritis and Undifferentiated Oligoarthritis and the Relative Importance of the Tests Used for Diagnosis," Annals of the Rheumatic Diseases, Vol. 60, No. 4, 2001, pp. 337-343. http://dx.doi.org/10.1136/ard.60.4.337

[51] M. K. Söderlin, H. Kautiainen, M. Puolakkainen, K. Hedman, M. Söderlund-Venermo, T. Skogh and M. LeirisaloRepo, "Infections Preceding Early Arthritis in Southern Sweden: A Prospective Population-Based Study," Journal of Rheumatology, Vol. 30, No. 3, 2003, pp. 459-464.

[52] M. G. Lacoste, H. Tamashiro, S. G. Correa, A. M. de Guzmán and M. S. Di Genaro, "Correlation between Yersinia enterocolitica and Type I Collagen Reactivity in Patients with Arthropathies," Rheumatology International, Vol. 27, No. 7, 2007, pp. 613-620. http://dx.doi.org/10.1007/s00296-006-0274-5

[53] J. Birnbaum, J. G. Bartlett and A. C. Gelber, “Clostridium difficile: An under-Recognized Cause of Reactive Arthritis?” Clinical Rheumatology, Vol. 27, No. 2, 2008, pp. 253-255. http://dx.doi.org/10.1007/s10067-007-0710-2

[54] P. Schiellerup, K. A. Krogfelt and H. Locht, “A Comparison of Self-Reported Joint Symptoms Following Infection with Different Enteric Pathogens: Effect of HLAB27," Journal of Rheumatology, Vol. 35, No. 3, 2008, pp. 480-487.

[55] T. Hannu, M. Puolakkainen and M. Leirisalo-Repo, “Chlamydia pneumoniae as a Triggering Infection in Reactive Arthritis," Rheumatology, Vol. 38, No. 5, 1999, pp. 411414.

[56] A. Rizzo, M. D. Domenico, C. R. Carratelli and R. Paolillo, "The Role of Chlamydia and Chlamydophila Infections in Reactive Arthritis,” Internal Medicine, Vol. 51, No. 1, 2012, pp. 113-117.

http://dx.doi.org/10.2169/internalmedicine.51.6228

[57] I. Galadari and H. Galadari, "Nonspecific Urethritis and Reactive Arthritis," Clinics in Dermatology, Vol. 22, No. 6, 2004, pp. 469-475. http://dx.doi.org/10.1016/j.clindermatol.2004.07.010

[58] M. K. Soderlin, E. Alasaarela and M. Hakala, "Reactive Arthritis Induced by Clostridium difficile Enteritis as a Complication of Helicobacter pylori Eradication," Clinical Rheumatology, Vol. 18, No. 4, 1999, pp. 337-338. http://dx.doi.org/10.1007/s100670050113

[59] D. W. Carlson and D. R. Finger, "Beaver Fever Arthritis,” Journal of Clinical Rheumatology, Vol. 10, No. 2, 2004, pp. 86-88. http://dx.doi.org/10.1097/01.rhu.0000120979.11380.16

[60] A. Sing, S. Bechtold, J. Heesemann, B. H. Belohradsky and H. Schmidt, "Reactive Arthritis Associated with Prolonged Cryptosporidial Infection,” Journal of Infection, Vol. 47, No. 2, 2003, pp. 181-184. http://dx.doi.org/10.1016/S0163-4453(03)00035-5

[61] B. Tejera, D. Grados, M. Martinez-Morillo and S. Roure, "Reactive Arthritis Caused by Blastocystis hominis," Reumatología Clinica, Vol. 8, No. 1, 2012, pp. 50-51.

[62] K. Granfors, R. Merilahti-Palo, R. Luukkainen, T. Mottonen, R. Lahesmaa, P. Probst, E. Marker-Hermann and P. Toivanen, "Persistence of Yersinia Antigens in Peripheral Blood Cells from Patients with Yersinia enterocolitica O:3 Infection with or without Reactive Arthritis," Arthritis \& Rheumatism, Vol. 41, No. 5, 1998, pp. 855-862. http://dx.doi.org/10.1002/1529-0131(199805)41:5<855:: AID-ART12>3.0.CO;2-J

[63] J. A. Curfs, J. G. Meis, H. L. Van Der Lee, J. Mulder, W. G. Kraak and J. A. Hoogkamp-Korstanje, "Persistent Yersinia enterocolitica Infection in Three Rat Strains,” Microbial Pathogenesis, Vol. 19, No. 1, 1995, pp. 57-63. http://dx.doi.org/10.1006/mpat.1995.0045

[64] M. Saarinen, L. J. Pelliniemi and K. Granfors, "Survival and Degradation of Salmonella enterica Serotype Enteritidis in Intestinal Epithelial Cells in Vitro," Journal of Medical Microbiology, Vol. 45, No. 6, 1996, pp. 463-471. http://dx.doi.org/10.1099/00222615-45-6-463

[65] J. Braun, Z. Yin, I. Spiller, S. Siegert, M. Rudwaleit, L. Liu, A. Radbruch and J. Sieper, "Low Secretion of Tumor Necrosis Factor Alpha, but No Other Th1 or Th2 Cytokines, by Peripheral Blood Mononuclear Cells Correlates with Chronicity in Reactive Arthritis," Arthritis \& Rheumatism, Vol. 42, No. 10, 1999, pp. 2039-2044.

http://dx.doi.org/10.1002/1529-0131(199910)42:10<2039 :AID-ANR3>3.0.CO;2-6

[66] I. Butrimiene, S. Jarmalaite, J. Ranceva, A. Venalis, L. Jasiuleviciute and A. Zvirbliene, "Different Cytokine Profiles in Patients with Chronic and Acute Reactive Arthritis,” Rheumatology, Vol. 43, No. 10, 2004, pp. 1300-1304. http://dx.doi.org/10.1093/rheumatology/keh323

[67] H. Shen, J. C. Goodall and J. S. Gaston, "Frequency and Phenotype of T Helper 17 Cells in Peripheral Blood and Synovial Fluid of Patients with Reactive Arthritis," Journal of Rheumatology, Vol. 37, No. 10, 2010, pp. 20962099. http://dx.doi.org/10.3899/jrheum.100146

[68] R. J. Eliçabe, E. Cargnelutti, M. I. Serer, P. W. Stege, S. R. Valdez, M. A. Toscano, G. A. Rabinovich and M. S. Di Genaro, "Lack of TNFR p55 Results in Heightened Expression of IFN- $\gamma$ and Il-17 During the Development of Reactive Arthritis,” Journal of Immunology, Vol. 185, No. 7, 2010, pp. 4485-4495. http://dx.doi.org/10.4049/jimmunol.0902245

[69] E. Cargnelutti, J. L. Arias, S. R. Valdez, G. A. Rabinovich and M. S. Di Genaro, "TNFR p55 Controls Regulatory T Cell Responses in Yersinia-Induced Reactive Arthritis," Immunology and Cell Biology, Vol. 91, No. 2, 2013, pp. 159-166. http://dx.doi.org/10.1038/icb.2012.65

[70] J. Sieper, J. Braun, P. Wu and G. Kingsley, “T Cells Are 
Responsible for the Enhanced Synovial Cellular Immune Response to Triggering Antigen in Reactive Arthritis," Clinical \& Experimental Immunology, Vol. 91, No. 1, 1993, pp. 96-102.

http://dx.doi.org/10.1111/j.1365-2249.1993.tb03361.x

[71] C. Alvarez-Navarro, J. J. Cragnolini, H. G. Dos Santos, E. Barnea, A. Admon, A. Morreale and J. A. López De Castro, "Novel HLA-B27-Restricted Epitopes from Chlamydia trachomatis Generated Upon Endogenous Processing of Bacterial Proteins Suggest a Role of Molecular Mimicry in Reactive Arthritis," Journal of Biological Chemistry, Vol. 288, No. 36, 2013, pp. 25810-25825. http://dx.doi.org/10.1074/jbc.M113.493247

[72] R. Benjamin and P. Parham, "Guilt by Association: HLAB27 and Ankylosing Spondylitis," Immunology Today, Vol. 11, No. 4, 1990, pp. 137-142. http://dx.doi.org/10.1016/0167-5699(90)90051-A

[73] W. Kuon, H. G. Holzhutter, H. Appel, M. Grolms, S. Kollnberger, A. Traeder, P. Henklein, E. Weiss, A. Thiel, R. Lauster, P. Bowness, A. Radbruch, P. M. Kloetzel and J. Sieper, "Identification of HLA-B27-Restricted Peptides from the Chlamydia trachomatis Proteome with Possible Relevance to HLA-B27-Associated Diseases," Journal of Immunology, Vol. 167, No. 8, 2001, pp. 4738-4746.

[74] E. May, M. L. Dorris, N. Satumtira, I. Iqbal, M. I. Rehman, E. Lightfoot and J. D. Taurog, "CD8 Alpha Beta T Cells Are Not Essential to the Pathogenesis of Arthritis or Colitis in HLA-B27 Transgenic Rats," Journal of Immunology, Vol. 170, No. 2, 2003, pp. 1099-1105.

[75] J. D. Taurog, M. L. Dorris, N. Satumtira, T. M. Tran, R. Sharma, R. Dressel, J. Van Den Brandt and H. M. Reichardt, "Spondylarthritis in HLA-B27/Human Beta2-Microglobulin-Transgenic Rats Is Not Prevented by Lack of CD8," Arthritis \& Rheumatism, Vol. 60, No. 7, 2009, pp. 1977-1984. http://dx.doi.org/10.1002/art.24599

[76] M. A. Whelan and J. R. Archer, "Chemical Reactivity of an HLA-B27 Thiol Group,” European Journal of Immunology, Vol. 23, No. 12, 1993, pp. 3278-3285. http://dx.doi.org/10.1002/eji.1830231233

[77] R. A. Colbert, T. M. Tran and G. Layh-Schmitt, "HLAB27 Misfolding and Ankylosing Spondylitis,” Molecular Immunology, Vol. 57, No. 1, 2014, pp. 44-51. http://dx.doi.org/10.1016/j.molimm.2013.07.013

[78] L. H. Boyle, J. C. Goodall, S. S. Opat and J. S. Gaston, "The Recognition of HLA-B27 by Human CD4(+) T Lymphocytes,” Journal of Immunology, Vol. 167, No. 5, 2001, pp. 2619-2624.

[79] J. D. Reveille, "Genetics of Spondyloarthritis-Beyond the MHC," Nature Reviews Rheumatology, Vol. 8, No. 5, 2012, pp. 296-304. http://dx.doi.org/10.1038/nrrheum.2012.41

[80] J. D. Carter, H. C. Gerard, J. A. Whittum-Hudson and A. P. Hudson, "Combination Antibiotics for the Treatment of Chlamydia-Induced Reactive Arthritis: Is a Cure in Sight?” International Journal of Clinical Rheumatology, Vol. 6, No. 3, 2011, pp. 333-345. http://dx.doi.org/10.2217/ijr.11.20

[81] J. Sieper, "Developments in Therapies for Spondyloarthritis,” Nature Reviews Rheumatology, Vol. 8, No. 5, 2012, pp. 280-287. http://dx.doi.org/10.1038/nrrheum.2012.40

[82] A. Toivanen, "Managing Reactive Arthritis," Rheumatology, Vol. 39, No. 2, 2000, pp. 117-119.

http://dx.doi.org/10.1093/rheumatology/39.2.117

[83] M. Dougados, "Current Therapy for Seronegative Arthritides (Spondyloarthritis)," Bulletin of the NYU Hospital for Joint Diseases, Vol. 69, No. 3, 2011, pp. 250-252.

[84] D. Flores, J. Marquez, M. Garza and L. R. Espinoza, "Reactive Arthritis: Newer Developments," Rheumatic Disease Clinics of North America, Vol. 29, No. 1, 2003, pp. 37-59. http://dx.doi.org/10.1016/S0889-857X(02)00081-9

[85] D. O. Clegg, D. J. Reda, M. H. Weisman, J. J. Cush, F. B. Vasey, H. R. Schumacher Jr., E. Budiman-Mak, D. J. Balestra, W. D. Blackburn, G. W. Cannon, R. D. Inman, F. P. Alepa, E. Mejias, M. R. Cohen, R. Makkena, M. L. Mahowald, J. Higashida, S. L. Silverman, N. Parhami, J. Buxbaum, C. M. Haakenson, R. H. Ward, B. J. Manaster, R. J. Anderson, W. G. Henderson, et al., "Comparison of Sulfasalazine and Placebo in the Treatment of Reactive Arthritis (Reiter's Syndrome). A Department of Veterans Affairs Cooperative Study," Arthritis \& Rheumatism, Vol. 39, No. 12, 1996, pp. 2021-2027. http://dx.doi.org/10.1002/art.1780391211

[86] L. Goh and A. Samanta, "Update on Biologic Therapies in Ankylosing Spondylitis: A Literature Review," International Journal of Rheumatic Diseases, Vol. 15, No. 5, 2012, pp. 445-454. http://dx.doi.org/10.1111/j.1756-185X.2012.01765.x

[87] S. D. Flagg, R. Meador, E. Hsia, T. Kitumnuaypong and H. R. Schumacher, "Decreased Pain and Synovial Inflammation after Etanercept Therapy in Patients with Reactive and Undifferentiated Arthritis: An Open-Label Trial,” Arthritis Care \& Research, Vol. 53, No. 4, 2005, pp. 613617. http://dx.doi.org/10.1002/art.21323

[88] R. Meador, E. Hsia, T. Kitumnuaypong and H. R. Schumacher, "TNF Involvement and Anti-TNF Therapy of Reactive and Unclassified Arthritis," Clinical and Experimental Rheumatology, Vol. 20, No. 6, 2002, pp. S130S134.

[89] A. Meyer, E. Chatelus, D. Wendling, J. M. Berthelot, E. Dernis, E. Houvenagel, J. Morel, O. Richer, T. Schaeverbeke, J. E. Gottenberg and J. Sibilia, "Safety and Efficacy of Anti-Tumor Necrosis Factor Alpha Therapy in Ten Patients with Recent-Onset Refractory Reactive Arthritis,” Arthritis \& Rheumatism, Vol. 63, No. 5, 2011, pp. 12741280. http://dx.doi.org/10.1002/art.30272

[90] K. S. Oili, H. Niinisalo, T. Korpilahde and J. Virolainen, "Treatment of Reactive Arthritis with Infliximab," Scandinavian Journal of Rheumatology, Vol. 32, No. 2, 2003, pp. 122-124. http://dx.doi.org/10.1080/03009740310000157

[91] M. Rihl, A. Klos, L. Kohler and J. G. Kuipers, "Infection and Musculoskeletal Conditions: Reactive Arthritis," Best Practice \& Research Clinical Rheumatology, Vol. 20, No. 6, 2006, pp. 1119-1137. http://dx.doi.org/10.1016/j.berh.2006.08.008

[92] M. D. Schafranski, "Infliximab for Reactive Arthritis Secondary to Chlamydia trachomatis Infection," Rheuma- 
tology International, Vol. 30, No. 5, 2010, pp. 679-680. http://dx.doi.org/10.1007/s00296-009-0965-9

[93] R. J. Eliçabe, J. L. Arias, G. A. Rabinovich and M. S. Di Genaro, "TNFRp55 Modulates IL-6 and Nitric Oxide Responses Following Yersinia Lipopolysaccharide Stimulation in Peritoneal Macrophages," Immunobiology, Vol. 216, No. 12, 2011, pp. 1322-1330. http://dx.doi.org/10.1016/j.imbio.2011.05.009

[94] A. Gottlieb, A. Menter, A. Mendelsohn, Y. K. Shen, S. Li, C. Guzzo, S. Fretzin, R. Kunynetz and A. Kavanaugh, "Ustekinumab, a Human Interleukin 12/23 Monoclonal Antibody, for Psoriatic Arthritis: Randomised, DoubleBlind, Placebo-Controlled, Crossover Trial,” Lancet, Vol. 373, No. 9664, 2009, pp. 633-640. http://dx.doi.org/10.1016/S0140-6736(09)60140-9

[95] I. B. Mcinnes, J. Sieper, J. Braun, P. Emery, D. Van Der Heijde, J. D. Isaacs, G. Dahmen, J. Wollenhaupt, H. Schulze-Koops, J. Kogan, S. Ma, M. M. Schumacher, A.
P. Bertolino, W. Hueber and P. P. Tak, "Efficacy and Safety of Secukinumab, a Fully Human Anti-Interleukin17A Monoclonal Antibody, in Patients with Moderateto-Severe Psoriatic Arthritis: A 24-Week, Randomised, Double-Blind, Placebo-Controlled, Phase II Proof-of-Concept Trial," Annals of the Rheumatic Diseases, 2013.

[96] M. Leirisalo-Repo, P. Helenius, T. Hannu, A. Lehtinen, J. Kreula, M. Taavitsainen and S. Koskimies, "Long-Term Prognosis of Reactive Salmonella Arthritis," Annals of the Rheumatic Diseases, Vol. 56, No. 9, 1997, pp. 516520. http://dx.doi.org/10.1136/ard.56.9.516

[97] M. Leirisalo-Repo and H. Suoranta, "Ten-Year Follow-up Study of Patients with Yersinia Arthritis," Arthritis \& Rheumatism, Vol. 31, No. 4, 1988, pp. 533-537. http://dx.doi.org/10.1002/art.1780310410

[98] E. Sairanen, I. Paronen and H. Mähönen, "Reiter’s Syndrome: A Follow-up Study,” Acta Medica Scandinavica, Vol. 185, No. 1-6, 1969, pp. 57-63. 